\title{
НАРОЩЕННЯ ІНВЕСТИЦІЙНОГО ПОТЕНЦІАЛУ КАРПАТСЬКОГО РЕГІОНУ ШЛЯХОМ ВИКОРИСТАННЯ КРАУД-ТЕХНОЛОГІЙ
}

\author{
Бандура Тетяна Іванівна \\ аспірант \\ ДУ «Інститут регіональних досліджень ім. М.І. Долішнього НАН України» (м. Львів, Україна) \\ ORCID ID: 0000-0001-7183-8714 \\ tanyaband@ukr.net
}

\begin{abstract}
У статті досліджено світовий досвід використання крауд-технологій. Розелянуто трактування та основний зміст краудсорсингу, краудфрандингу та краудінвестингу. Визначено переваги та ризики для усіх учасників краудфрандингових платформ. Запропоновано використання крауд-технологій як інструменту нарощення інвестиційного потенціалу Карпатського регіону. Обгрунтовано доцільність розроблення нормативно-правової документації з питань краудфандингу органами законодавчої влади. Доведено необхідність створення краудфрандингової платформи Карпатського регіону як комунікативного майданчика між бізнесом і громадою та інфформування про ії можливості громадянам. Охарактеризовано n'ять режимів регулювання фінансових моделей краудфрандингу, які використовуються у світовій економіці. Наголошено на доиільності використання краудінвестингу для залучення іноземних та вітчизняних інвестицій. Запропоновано інфрормування влади, бізнесу та громади про можливості використання краудсорсингу, краудфрандингу, краудінвестингу. Доведено доцільність використання крауд-технологій у економіці Карпатського регіону комплексно (пакетно).
\end{abstract}

Ключові слова: крауд-технології, краудфрандине, Карпатський регіон, інвестиційний потенціал, інвестииіії, фінансові моделі краудфрандингу.

DOI: https://doi.org/10.32845/bsnau.2019.4.22

Постановка проблеми. Нерівномірність розвитку прикордонних територій Карпатського регіону зумовлена багатьма факторами. Попри диспропорції у регіоні можливе використання дієвого інструментарію для їх нівелювання. Світовий досвід пропонує інноваційні технології для залучення інвестицій у регіон, які дозволять створювати нові робочі місця, сприятимуть збільшенню обсягу податкових відрахувань, покращенню показників соціально-економічного розвитку тощо. Беззаперечно, залучення інвестицій сприяє налагодженню зв'язків між регіонами та країнами світу. Співпраця 3 партнерами-країнами в сффері інвестиційної діяльності продукуватиме гармонійні відносини та подальший розвиток стосунків не тільки на економічному рівні, але й в інших сфрерах діяльності.

Аналіз останніх досліджень та публікацій. Роль крауд-технологій в регіональному розвитку досліджували зарубіжні вчені: Велс Л, Вінт А, Морісет Дж. та вітчизняні науковці: Сухарська Л.В., Зозульов О.В, Кухта К.О., Пастернак O.I. Однак на сьогодні залишається невирішеним питання, яким чином використовувати на практиці крауд-технології, для залучення інвестицій в економіку регіону.

Формування цілей статті. Метою даного дослідження $є$ обгрунтування перспектив використання краудтехнологій як сучасного інструменту нарощення інвестиційного потенціалу Карпатського регіону.

Виклад основного матеріалу. Світовий досвід пропонує сучасні інструменти нарощення інвестиційного потенціалу серед яких крауд-технології, які виконують багато функцій: формують сприятливий інвестиційний клімат та позитивний імідж регіону, дозволяють залучити інвестиційні ресурси не фінансових установ та населення, сприяють комунікації бізнесу, громади та влади.

Крауд-технології дозволяють вирішити ще одну актуальну проблему -подолання рівня недовіри громадян інвестувати у економіку регіону. Зважаючи на те, що більшість лю-

дей усвідомлює свою приналежність до території, де проживає, і відчуває бажання бути причетним до розвитку спільних територій, вони готові вкладати в регіональні проекти та проекти, які територіально близькі і несуть суспільний інтерес, та в подальшому підвищать рівень соціально-економічного розвитку регіону.

Такі види крауд-технологій як краудсорсинг, краудфандинг, краудінвестинг, на думку експертів, є інноваційними фінансовими інструментами у питаннях реалізації місцевих проектів та ініціатив розвитку регіону.

Краудсорсинг передбачає передачу певних виробничих функцій необмеженому колу осіб-добровольців для вирішення суспільно значущих завдань переважно за допомогою сучасних інформаційних технологій [1].

Іншими словами, краудсорсинг- це використання потенціалу певної групи людей для вирішення певних завдань на добровільних засадах.

Лінус Торвальдс вперше використав технології краудсорсингу у створенні операційної системи Linux. Цей проект започаткував напрям у галузі IT, а саме створенні програмного забезпечення Open Source. Обговорення програми Windows 7 в мережі у 2009 р. на стадії іï розробки також використовувало крауд-технології. Внаслідок цього обговорення розробники максимально врахували побажання і вимоги користувачів, що випробували операційну систему.

Прикладом краудсорсингу на державному рівні $\epsilon$ представлення та обговорення Ісландією конституції на сторінці соціальної мережі Facebook.

Краудсорсинг включає наступні етапи:

- організація (збір, оброблення інфрормації та конструктивних ідей);

- методологія (збір пропозицій до проектів);

- згуртована робота підготовленого персоналу (для отримання консолідованої інфрормації від незалежних експертів).

Краудсорсинг - це інструмент для генерування ідей у

Вісник Сумського національного аграрного університету 
всіх галузях діяльності.

Крауд-технології використовують не тільки у бізнесі, але і для ефективної комунікації органів управління з громадськістю. Краудсорсинг у регіоні сприятиме залученню мешканців територій до вирішення проблем, які виникають в регіоні (на даній території) шляхом висловлення пропозицій та ідей, застосування власних знань та досвіду.

Краудфандинг - це колективне співробітництво осібдонорів, які добровільно об'єднують свої фінансові або інші ресурси разом, як правило, через Інтернет для того, щоб підтримати зусилля інших осіб або організацій (реципієнтів) [2].

Іншими словами, краудфандинг - це інноваційний спосіб збору коштів, який не потребує великої кількості витрат. У краудфандингу беруть участь три сторони: автор проекту, спонсор (інвестор) та посередник (краудфандингова платформа). Посередник створює свій ресурс з ціллю організувати зустріч двох сторін на майданчику. Завдання краудфандингової платформи: аналіз проектів; збір коштів; контроль отримання автором коштів від посередника і їх повернення, якщо повна сума не була зібрана.

Вигода платформи: оплата за організацію та супровід процесу збору коштів. Беззаперечно $є$ наявні переваги для автора і спонсора в процесі краудфандингу, але є і ризики для учасників.

Ризики полягають у недобросовісності авторів проекту, шахрайстві, відсутності якісної перевірки бізнес-проектів та визначених правил повернення коштів, які не зібрані в тому обсязі, щоб запустити проект. Краудфандингові платформи, у разі припинення їх роботи, позбавляють автора і спонсора фінансових розрахунків за схемою, укладеною трьома сторонами.

Найсуттєвішою проблемою є відсутність законодавчої бази для реалізації даних технологій в Україні. Внаслідок цього, існуючі платформи змушені будувати певні юридичні моделі в рамках загальних норм законодавства, що спричиняє значні витрати та «хитке» правове становище. Діяльність краудфандингових майданчиків можна підпорядковувати під поняття реалізації «фінансових послуг», а можна і трактувати як «інші послуги». Через відсутності чіткого законодавства у цій сфері, велика кількість проектів, через сумніви авторів реалізовується через відповідні платформи інших країн, де краудфандингова діяльність описана в нормативно-правових документах.

Для стимулювання розвитку краудфандингу у Карпатському регіоні необхідне створення нормативно-правової бази, яка буде регламентувати взаємодію учасників та вирішення спорів краудфандингового процесу. Держава повинна створити умови розвитку для краудфандингу, належно опрацювати та викласти у нормативно-правовому акті процедуру організації та регулювання краудфандингових платформ. Слід врахувати, що правове регулювання повинно стимулювати і підтримувати платформи, і не створювати перешкоди чи обмеження для їх функціонування. Влада повинно всіляко підтримувати створення та діяльність краудфандингових платформ, як інструменту залучення інвестицій в умовах невизначеності чи кризи. Як показує досвід країни в умовах пандемії 2020 року, потрібно переорієнтовувати бізнес в режим онлайн, і інвестиційний ринок також повинен відкрити перед собою таку можливість.

Прийняття закону про краудфандинг 3 трактуванням визначення категорії та з роз'ясненням усіх зобов'язань сторін-учасників процесу буде першим етапом. Наступним має бути популяризація та сприяння створенню краудфандингових платформ.

Краудінвестинг - форма інвестування, аналогічна краудфандингу, але має свої відмінності. Краудінвестинг дозволяє інвестору очікувати відносно високих доходів, у разі успіху обраної компанії, але з розумінням можливих високих ризиків [3].

Стартував краудінвестинг, як самостійна концепція тільки в 2012 році, чому сприяв підписаний президентом США Б. Обамою JOBS Act, який дозволив займатися інвестиціями не тільки кваліфікованим інвесторам, але й звичайним жителям США. У травні 2016 року нарешті набрала чинності глава 3 Jumpstart Our Business Startups Act (JOBS Act), яка усунула бар'єри для краудінвестингу [4].

В Україні крауд-технології тільки починають розвиватись. Найвідомішою краудфандинговою платформою $€$ Спільнокошт. На цьому майданчику можна знайти фрінансування для соціальних, мистецьких проектів, винаходів.

у Карпатському регіоні Львівською Політехнікою у 2019 р. було засновано майданчик StartEra, інноваційну краудфандингову платформу для розміщення і просування творчих, соціальних і технологічних проектів, а також громадських ініціатив за фінансової підтримки з боку тих, хто вболіває за розвиток і реалізацію інновацій в Україні.

Слід зазначити, що є велика відмінність платформ, які працюють з соціальними та мистецькими ініціативами від тих, які допомагають реалізовувати бізнес-проекти. Якщо в Україні з'явились майданчики, що допомагають реалізувати благодійні та соціальні проекти, то майданчика суто для бізнесу ще немає, через ризики та нерозвиненість краудфандингу, відсутність законодавчої бази. Тому, вбачаємо доцільність розроблення краудфандингових та краудінвестингових платформ з брендом Карпатського регіону та з ціллю залучити інвесторів до співпраці з бізнес-проектами та ініціативами в регіоні. Такі ресурси повинні бути двомовними (українська та англійська) з метою зацікавлення іноземних інвесторів.

Практична реалізація краудфандингу здійснюється шляхом створення

спеціальної інтернет-платформи. Найуспішнішою краудфандинговою платформою була Kickstarter, заснована у 2009 р. в США. Завдяки платформі було профінансовано понад 39 тис. проектів. 3,9 млн. чоловік отримали 579 млн USD. На сьогодні в розвинених країнах працює багато платформ, де мешканці регіону фінансують усі сфери: від благодійності до стартапів. США є лідером з краудфандингу- 344 платсорми, наступне місце посідає Великобританія - 87, а третє місце Франція - 53.

Крауд-технології є цікавими для використання «пакетно», тобто: краудсорсинг дає можливості отримати думку жителів, їх пропозиції та можливі шляхи усунення недоліків чи шляхи покращення ситуації на певній території, а отримані згенеровані ідеї можливо втілити за рахунок краудфандингових та краудінвестингових платформ з залученням фінансування зацікавлених сторін. За кордоном безліч проектів отримують фінансування таким шляхом і успішно реалізовуються. Найбільшою проблемою на теперішній час $є$ домовленість (співпраця) громади та представників місцевої влади та взаєморозуміння наявних проблем.

Вісник Сумського національного аграрного університету 
За кордоном та і в Україні є велика кількість людей та організацій готові фрінансувати цікаві проекти, спрямовані на економічний розвиток територій. Проблемою є пошук об'єктів вкладень, тобто зустріч попиту з пропозицією у зручному форматі. Краудфандингові та краудінвестингові платфрорми $€$ цікавим майданчиком пошуку для обидвох сторін.

Прикладом реалізації місцевими громадами ініціатив за допомогою краудфандингу $€$ європейська платформа Spacehive, яка спеціалізується на пошуку фінансування місцевими громадами проектів. Краудфандинг $€$ одним 3 ефективних інструментів не тільки залучення фрінансування мешканцями столиці Великобританії, а й об'єднання досвіду та знань населення, зацікавленого у реалізації місцевих проектів.

Перевагою краудфандингу $€$ відсутність обмежень щодо залучення коштів та кількість учасників. Навіть невеликі вкладення $є$ важливими, а учасники отримують задоволення від участі в вирішенні проблем регіону чи території, на якій проживають. Також, краудфандинг дозволяє одночасно фінансувати кілька проектів, які реалізуються в регіоні, і не виключає можливості отримання прибутку, чим, власне, є цікавий населенню інвестувати власні заощадження 3 мінімальними ризиками. В силу нестабільної політичної ситуації та недовіри до фінансових установ, яка склалась в країні, краудфандинг дасть можливість жителям регіону вкладати власні кошти і отримувати прибутки.

International Organization of Securities Commissions (IOSCO) стверджує, що зараз у світі можна виокремити п'ять режимів, які мають мету регулювання фінансових моделей краудфандингу у країнах: неврегульованість краудфандингу; регулювання через посередника; регулювання через банківську систему; регулювання згідно американської моделі; заборона.

Неврегульованість краудфандингу присутня в країнах, які не мають розвиненого кредитного ринку; відсутність визначення послуг, які надаються інвесторам та малий інвестиційний ринок (Туніс).

Регулювання через посередника, здебільшого, відбувається у країнах, де

існує система реєстрації краудфандингових платформ, ліцензування, правила діяльності тощо.

Регулювання через банківську систему присутня в країнах, де краудфандингові-платформи класифікуються як банківські установи, з функцією кредитного посередника, тому і регулюються банківською системою. Краудфандингові платформи повинні отримати ліцензію на банківську діяльність (Німеччина, Франція).

Американська модель пропонує, щоб кожна платформа була зареєстрована в Комісії з цінних паперів та на фондових біржах (SEC). Фінансова операція отримання коштів через краудфандингову платформу має реєструватись в SEC.
В Україні не розглядається жодний з режимів регулювання фінансових моделей краудфандингу. Краудфандингова діяльність потребує відповідного регулювання з метою уникнення випадків шахрайства, непорозумінь, некоректних дій учасників процесу. В зв'язку з тим, що ринок краудфандингу лише починає розвиватись у нашій країні, законодавство повинно уникати встановлення жорстких вимог, але одночасно надавати гарантії для усіх сторін-учасників краудфрандингу. Відсутність законодавчих норм на сьогодні не повинна обмежувати його розвиток і потенційні можливості для регіонів та країни.

Початковим етапом відповідного регулювання фрінансових моделей краудфандингу $€$ розроблення і впровадження в дію відповідного закону та створення державної краудфандингової платформи 3 акцентом на регіони 3 врахуванням децентралізованих процесів, які відбуваються в країні.

Це стане початком фінансового оздоровлення регіонів; залучення громадськості до вирішення соціально значущих завдань на території регіону; реалізації програм розвитку; підвищення ефективності діалогу влади, бізнесу та громади.

Крауд-технології, на думку експертів, є інноваційними фрінансовими інструментами у питаннях реалізації місцевих проектів та ініціатив розвитку регіону.

Вимогою сучасних реалій $€$ розробка дієвого механізму управління інвестиційними можливостями регіону, який повинен передбачати визначення пріоритетних напрямів інвестиційних вкладень з урахуванням економічних особливостей регіону. Одним з напрямів якого, повинно стати широке застосування крауд-технології, як інструменту залучення інвестицій у регіон, як внутрішніх так і зовнішніх.

Суспільство майбутнього орієнтоване на імплементацію нових успішних соціально-орієнтованих бізнес моделей. Трансформація економіки відбувається постійно, зважаючи на світові кризи, зміну мислення соціуму та розвиток. Просвітницька діяльність передбачає інформування та ознайомлення з інноваційними продуктами та технологіями для формування та закладення мислення соціуму, яке зможе вийти за межі уявлень і спроектувати нові можливості для розвитку економіки та суспільства вцілому.

Висновки. Отже крауд-технологій є дієвим інструментом нарощення інвестиційного потенціалу Карпатського регіону. Створення крауд-фандингової платформи Карпатського регіону дозволить залучати бізнес та громаду до участі у інвестиційному процесі регіону. Для успішного функціонування таких платформ необхідна розробка нормативно-правових актів, які регулюватимуть функції крауд-фандингових платформ та вирішення спорів, які можуть виникати.

\section{Список використаної літератури:}

1. Wells L., Wint A. Marketing a country : promotion as a tool for attracting foreign investment (revised edition). Washington, D.C., 2000. 192 p. URL: http://documents.worldbank.org/curated/en/884891468763824660/Marketing-a-country-promotion-as-a-toolfor-attracting-foreign-investment-revised-edition

2. Morisset, J. Does a country need a promotion agency to attract foreign direct investment: a small analytical model applied to 58 countries. Washington, D.C., 2003. 26 p. URL: http://documents.worldbank.org/curated/en/977191468739488998/Does-a-country-need-a-promotion-agency-to-attract-foreign-direct-investment-a-small-analytical-model-applied-to-58-countries 
3. Краудінвестинг або краудфандинг: чи є перспективи розвитку в Україні?: сайт. URL: http://nardepjournal.com/article/2013/95/KRAUDINVESTING-ABO KRAUDFANDING-Chl-E-PERSPEKTIVI-ROZVITKU-V-UKRAINI

4. Краудфандинг. Історія законодавчого підкріплення у США.: сайт. URL: http://molodyvcheny.in.ua/files/journal/ 2014/12/89.pdf

5. Сухарська Л. В. Аналіз стану фінансового забезпечення розвитку об'єднаних територіальних громад в сучасній Україні. Державне управління: теорія та практика. 2017. № 1. С. 92-101.

6. Pasternak O., Bandura T. Marketing of rural territories in the border areas of Ukraine: nature, peculiarities and practical recommendations. Agricultural Economics and Rural Development. 2017. №2. P.185-195.

\section{References:}

1. Wells, L., Wint, A. (2000). Marketing a country : promotion as a tool for attracting foreign investment (revised edition). Foreign investment advisory service occasional paper ; no. FIAS 13 Washington, D.C. : World Bank Group. URL: http://documents.worldbank.org/curated/en/884891468763824660/Marketing-a-country-promotion-as-a-tool-for-attracting-foreigninvestment-revised-edition

2. Morisset, J. (2003). Does a country need a promotion agency to attract foreign direct investment: a small analytical model applied to 58 countries. Policy, Research working paper series ; no. WPS 3028 Washington, D.C. : World Bank Group. URL: http://documents. worldbank.org/curated/en/977191468739488998/Does-a-country-need-a-promotion-agency-to-attract-foreigndirect-investment-a-small-analytical-model-applied-to-58-countries

3. Kraudinvestynh abo kraudfandynh: chy ye perspectyvy rozvytku v Ukrayini? [Crowdinvesting or crowdfunding: are there the development perspectives for Ukraine?] (2013). URL: http://nardepjournal.com/article/2013/95/KRAUDINVESTING-ABO KRAUDFANDING-Chl-E-PERSPEKTIVI-ROZVITKU-V-UKRAINI

4. Kraudfandynh. Istoriya zakonodavchoho pidkroplennya u SSHA [Crowdfunding. History of the legal framework in the US] (2014). URL: http://molodyvcheny.in.ua/files/journal/ 2014/12/89.pdf

5. Suharska L. V. (2017). Analiz stanu finansovoho zabezpechennya rozvytku obyednanyh terytorialnyh hromad v suchasniy Ukrayini [Analysis of the condition of financial maintenance of the territorial communities' development in modern Ukraine]. Derzhavne upravlinnya: teoriya ta praktyka - Public governance: theory and practice, 1, 92-101.

6. Pasternak, O., Bandura T. (2017). Marketing of rural territories in the border areas of Ukraine: nature, peculiarities and practical recommendations. Agricultural Economics and Rural Development, 2, 185-195.

Bandura Tetyana, PhD student, SI "The Institute of Regional Research Named after M.I. Dolishiny of the NAS of Ukraine" (Lviv, Ukraine)

Improving the investment capacity of the Carpathian region through the use of crowd-technologies

The paper researches the global experience of the use of crowd-technologies. The interpretation and main content of crowdsourcing, crowdfunding, and crowdinvesting are outlined. The advantages and risks for all participants of the crowdfunding platforms are determined. The use of crowd-technologies as a tool to increase the investment capacity of the Carpathian region is suggested. The reasonability of developing the regulative documents on crowdfunding by legislative authorities is explained. The need to create the crowd-funding platform of the Carpathian region as a communicative ground for businesses and communities and to raise public awareness about its capacities is proven. Five regimes of crowdfunding model regulation used worldwide are characterized. The reasonability of the use of crowdinvesting to attract foreign and domestic investment is emphasized. The practical use of crowdsourcing at the regional level is displayed on the example of best global practices. The advantages obtained by a community by communication with authorities through the use of crowdsourcing are outlined. The informing of authorities, business, and community on the opportunities to use crowdsourcing, crowdfunding, and crowdinvesting are suggested. The reasonability of the use of crowdtechnologies in the economy of the Carpathian region complexly (in a package) is proven. The use of crowd-technologies is substantiated to be the innovative instrument of investment attraction and investment capacity increase in the Carpathian region.

Key words: crowd-technologies, crowdfunding, Carpathian region, investment capacity, investment, crowdfunding financial models

Дата надходження до редакції: 26.10.2019 р. 